\title{
Sprawozdanie z wyjazdu do Biblioteki Polskiej w Paryżu 3 października - 1 grudnia 2017 r.
}

Tegoroczny wyjazd był moim siódmym z kolei (poprzednie w latach 2008-2013 i 2015-2016) w ramach programu Ministra Kultury i Dziedzictwa Narodowego „Dziedzictwo Kulturowe”, priorytet „Ochrona dziedzictwa kulturowego za granica”, zadanie „Porządkowanie zbiorów archiwalnych za granicą".

W czasie pobytu zinwentaryzowałem 154 mapy z serii „Mapy XIX w.” i 73 plany miast i bitew z serii „Plany miast i bitew XIX w.” (razem 225 map i planów - sygnatury II 136289, II $1 \mathrm{Pv}-$ II $45 \mathrm{Pv}$, II $1 \mathrm{~Pb}$ - II $28 \mathrm{~Pb}$ ) oraz osiem atlasów ( sygnatury C II 1, 2, 3, 5, 273, 274, 275, 349). Przeprowadziłem razem z kierowniczką Oddziału Kolekcji Artystycznych dr Anną Czarnocką skontrum wszystkich atlasów (327 sztuk). Rozsegregowałem mapy po dezynfekcji i zinwentaryzowałem mapy XIX-wieczne, które pozostawały dotychczas bez ewidencji. Opracowanie map wymagało żmudnej i czasochłonnej kwerendy naukowej (np. ustalenie autora, daty wydania, dzieła, w którym mapa była zamieszczona), co zajęło dużo czasu. Do zakończenia opracowania tej części zbioru kartograficznego pozostało kilkanaście map ściennych i ponad 100 atlasów.

W czasie pobytu wybrano także z zasobu Biblioteki mapy do wystawy planowanej na 2018 r. „Walka o granice odrodzonej Polski”.

Oprócz prac nad opracowaniem zasobu brałem udział w bieżącej działalności Biblioteki (np. pomoc w demontażu wystawy poświęconej gen. Józefowi Hallerowi).

W czasie mojej bytności w Bibliotece Polskiej odbywały się liczne imprezy kulturalne i naukowe. Można było obejrzeć wystawy: „Les Vampires de guerre de Boleslas Biegas”, „Krzysztof Jung: Arbres et visages”, „Mécislas Golberg (1869-1907) dans les collections de la Société Historique et Littéraire Polonaise / Bibliothèque Polonaise de Paris", „Univers d'autographes. Les collections de la Société Historique et Littéraire Polonaise / Bibliothèque Polonaise de Paris sur l'Ile Saint-Louis" oraz ekspozycję prezentującą sylwetki i dorobek polskich inżynierów i techników działających we Francji (z okazji jubileuszu 100-lecia działalności Stowarzyszenia Inżynierów i Techników Polskich we Francji); wysłuchać licznych koncertów muzycznych oraz wziąć udział w wielu konferencjach i sympozjach naukowych, np.: „Kościuszko Héros de deux continents” (sympozjum towarzyszyła wystawa kopii rysunków wykonanych przez Kościuszkę w Akademii Rysunku i Rzeźby w Paryżu w latach 1767-1772), „Le général Józef Haller et l'Armée Bleue” wraz z wystawą poświęconą Generałowi i jego armii, „Oscar-Vladislas de Lubicz-Milosz. L'intouchable solitude d'un étranger”; „Les révolutions de 1917 en Russie et leurs conséquences pour la Pologne", wysłuchać wykładów prof. Jacques'a Legranda, byłego prezesa l'Institut National des Langues et Civilisations Orientales pt.,,Les Polonais en Mongolie du XII ${ }^{\mathrm{e}}$ au XXI ${ }^{\mathrm{e}}$ siècle”, Tadeusza Łubieńskiego „Histoire du cinéma polonais”. 
Zachęcam wszystkich wybierających się do Paryża, aby odwiedzili Bibliotekę Polską. Z godzinami otwarcia oraz programem kulturalnym można zapoznać się na stronie: http://www.bibliotheque-polonaise-paris-shlp.fr/.

Zbigniew Dyrdoń Archiwum Narodowe w Krakowie 